Vincenzo Leone ${ }^{1 *}$, Pasquale lovino ${ }^{1}$, Elio Coppola ${ }^{1}$, Stefano Salvestrini ${ }^{1}$, Sante Capasso ${ }^{2}$

${ }^{1}$ Second University of Naples, Department of Environmental, Biological and Pharmaceutical Science and Technologies, Caserta, Italy, ${ }^{2}$ University of Naples, Environmental Technologies University Spin-off, Second Caserta, Italy

Scientific paper ISSN 0351-9465, E-ISSN 2466-2585 UDC:620.196.649.67 doi: $10.5937 /$ ZasMat $1604515 \mathrm{~L}$

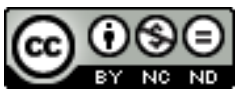

Zastita Materijala 57 (4) $515-518(2016)$

\title{
Sorption of organic pollutants onto zeolitic tuff
}

\begin{abstract}
The isotherms of sorption of six organic pollutants (phenylmethanol (benzyl alcohol), phenol, cyclohexanol, o-xylene, toluene and cyclohexane) from water solutions onto zeolitic tuff (Si/Al ratio $=2.4$ ) have been determined by batch experiments at $25^{\circ} \mathrm{C}$, in $1.0 \cdot 10^{-3} \mathrm{~mol} \mathrm{dm}{ }^{-3}$ Tris- $\mathrm{HCl}$ buffer, $\mathrm{pH}$ 6.0. The solutions were analyzed by gas-chromatography. The best description of the experimental data was given by the Freundlich equation, whose constants have been determined and compared with literature data.

Keywords: organic pollutants; zeolitic tuff; sorption.
\end{abstract}

\section{INTRODUCTION}

Natural zeolites are a class of microporous alumino-silicate minerals of common occurrence in volcanic ash deposits throughout the world. Because of their high ion-exchange capacity and relatively low cost, zeolites have been widely employed for water purification from ionic contaminants including heavy metals [1,2], radioactive cations [3] and ammonia [4]. The use of natural zeolite as sorbing material in permeable reactive barrier to treat heavy-metal contaminated waters has also been investigated [5]. Besides ionic solutes, zeolites also bind non-ionic organic molecules. Zeolite sorbitivity (amount of solute sorbed per unit dry mass of sorbant at the equilibrium) for these compounds depends mainly on the zeolite $\mathrm{Si} / \mathrm{Al}$ ratio, with high ratios increasing the hydrophobicity of the sorption sites and hence their affinity for non-polar molecules [6].

Here we report a study on the sorption of some organic pollutants onto a zeolitic tuff rich in phillipsite and charbazide and with a low Si/Al ratio (2.4), whose sorption properties towards cations have been characterized in previous work [7-9]. The aim of this study was to explore the behavior of this tuff toward organic pollutants of common occurrence in waste water, in the perspective of developing practical applications for water purification.

Corresponding author: Vincenzo Leone

E-mail: vincenzo.leone@unina2.it.

Paper received: 25.03.2016.

Paper accepted: 07.05.2016.

Paper is available on the website:

www.idk.org.rs/journal

\section{EXPERIMENTAL}

\subsection{Materials}

Analytical-grade phenylmethanol (benzyl alcohol), phenol, cyclohexanol, o-xylene, toluene and cyclohexane were purchased from Fluka (Germany). Methylene blue was purchased from Carlo Erba (Italy). A commercial sample of zeolitic tuff rich in phillipsite and chabazite (phillipsitechabazite tuff, PCT), Si/Al ratio 2.4, extracted from an outcrop of the Campanian Ignimbrite formation (yellow faces) in Comiziano (Napoli, Italy), was obtained from I.Z.-Italiana Zeoliti Company (Pigneto, Modena, Italy). The mineralogical and chemical characterization of this rock has been reported elsewhere [10]. The raw material was gently crashed and sieved to obtain grains in the range $0.5-1.0 \mathrm{~mm}$, and then washed several times with deionized water.

\subsection{Specific surface area determination}

The specific surface area (SSA) of PCT was determined with the methylene blue (MB) sorption method [11]. As MB can be sorbed by glass, polypropylene tubes were used. Fourteen $\mathrm{mL}$ aliquots of $\mathrm{MB}$ in deionized water, concentration range $1-11 \mathrm{mg} \mathrm{L}^{-1}$, were added to $4 \mathrm{mg}$ of ground PCT and kept at room temperature in a shaker at $60 \mathrm{rpm}$. At programmed times, the samples were centrifuged at $3000 \mathrm{rpm}$ for $10 \mathrm{~min}$ and analyzed by visible spectrophotometry at $665 \mathrm{~nm}$ (Perkin Elmer Lambda 40), using the calibration curve Absorbance $=0.2442 \cdot$ Conc $-0.0049 \cdot$ Conc $^{2}$ as determined from the concentration-absorbance plot. MB sorption was estimated by comparing its concentration in solution before and after contact 
with PCT. The SSA of PCT was calculated with the equation $S S A=q_{m} N_{A} A$, where $q_{m}$ is the monolayer capacity of PCT for MB in moles per gram; $N_{A}$ the Avogadro number and $A$ the surface area occupied per molecule of MB $\left(1.3 \cdot 10^{-22} \mathrm{~m}^{2}\right)$.

\subsection{Sorption experiments in batch}

The compounds selected were dissolved in water $\left(10-150 \mathrm{mg} \mathrm{L}^{-1}\right)$ containing $1.0 \cdot 10^{-3} \mathrm{~mol} \mathrm{dm}^{-3}$ Tris-HCl buffer, pH 6.0. For cyclohexane, because of its lower solubility in water, the higher concentration tested was $50 \mathrm{mg} \mathrm{L}^{-1}$. Twenty $\mathrm{mL}$ aliquots of each solution were mixed with $50 \mathrm{mg}$ of PCT in glass containers with a buthyl/PTFE cap and kept in a thermostat at $25{ }^{\circ} \mathrm{C}$ with periodical shaking. After seven days, $1.0 \mathrm{~mL}$ of solution was taken through the cap and analyzed by a Dani GC 1000 gas-chromatographer equipped with a spit/ splitless capillary inlet system, a FID detector and an ELITE 1 capillary column $(60 \mathrm{~m} \cdot 0.32 \mathrm{~mm}$, I.D. $5 \mu \mathrm{m}$ film thickness; Perkin Elmer). Measurements performed after longer times gave much the same results as after seven day incubation, so the latter was adopted as the protocol procedure.

\section{RESULTS AND DISCUSSION}

The specific surface area (SSA) of the PCT material determined according to the procedure described in the previous section was $31 \pm 4 \mathrm{~m}^{2} / \mathrm{g}$, a value slightly lower than that reported $\left(49 \mathrm{~m}^{2} / \mathrm{g}\right)$ for a phillipsite-rich tuff from Jordan [7].

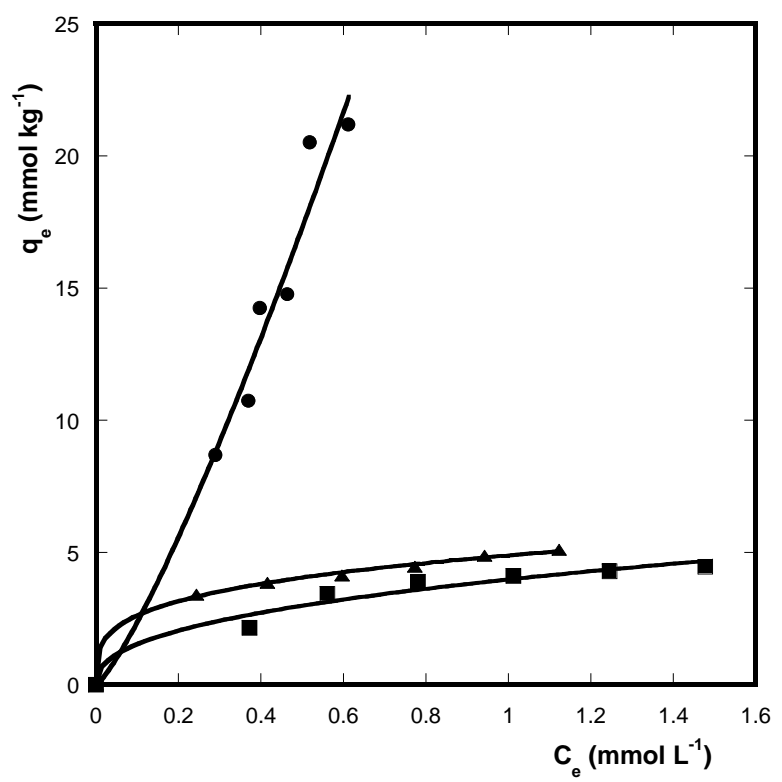

Figure 1 - Sorption isotherms of the hydrocarbon compounds toluene (a), o-xylene $\left((\boldsymbol{\Delta})\right.$ and cycloexane $(\bullet), \theta=25^{\circ} \mathrm{C} ; q_{e}$ is the sorbitivity, i.e. the amount of compound sorbed per unit mass of sorbent at the equilibrium, $\mathrm{Ce}$ is the compound concentration in solution at the equilibrium

The sorption isotherms for hydrocarbon and hydroxyl compounds are reported in Fig. 1 and 2, respectively.

Among the hydrocarbon compounds tested, the higher sorbitivity $\left(q_{e}\right)$ was observed for cyclohexane; moreover, in the concentration range analyzed, the $\mathrm{q}_{\mathrm{e}}$ for cyclohexane showed an almost linear relationship with $C_{e}$ (free sorbate concentration in solution at the equilibrium). Experiments at higher concentrations could not be performed because of low solubility in water. It is worth nothing that cycloexane has a higher octanol/water repartition coefficient $\left(\mathrm{K}_{\mathrm{OW}}\right)$ than all the other compounds tested (Table 1), and this, in our opinion, might account for the behavior observed: cycloexane does not "like" water, hence it is more prone to abandon the aqueous environment and bind to the sorbent.

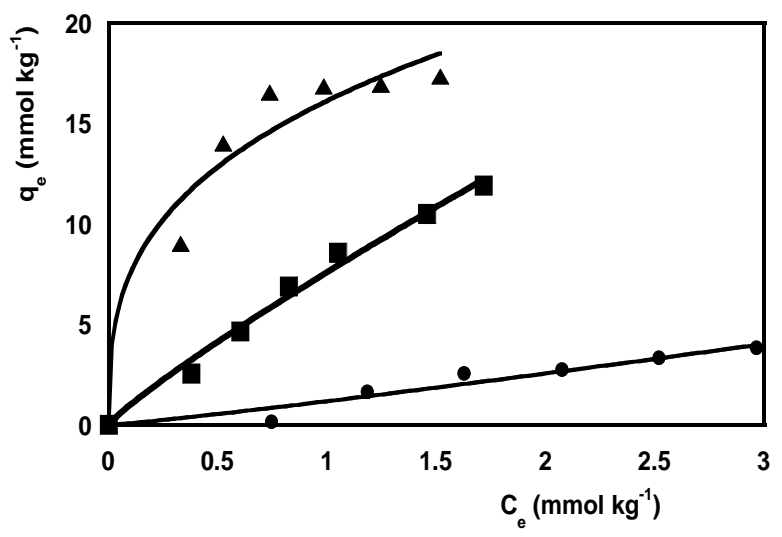

Figure 2 - Sorption isotherms of the hydroxyl compounds phenylmethanol (benzyl alcohol) ( $\mathbf{\Delta})$, phenol ( $\bullet$ ), and cyclohexanol $(\bullet), \theta=25^{\circ} \mathrm{C}$

In line with the above suggestion, the sorbitivity for hydroxyl compounds was lower than for hydrocarbon compounds and decreased with $\mathrm{K}_{\mathrm{ow}}$, with the minimum value being observed for phenylmethanol (Fig. 2 and Table 2).

The experimental sorption equilibrium data were analyzed using the equations of more common use, i.e. Langmuir, Fowler, bi-Langmuir, Freundlich and BET, $[12,13]$. On the base of the relative errors of the parameters and of the statistical $R^{2}$ parameters, the best description was given by the Freundlich equation, as expected considering the mineral heterogeneity of the zeolitic tuff tested:

$$
q_{e}=K_{F}\left(C_{e}\right)^{\frac{1}{n}}
$$

where $q_{e}$ and $C_{e}$ are respectively the amount of solute bound per unit mass of sorbent and the 
free solute concentration in solution, at the equilibrium. $K_{F}$ and $n$ are constants (Table 1 ).

Table 1 - Freundlich parameters of sorption onto a zeolitic tuff and logarithm of the n-octanol/water repartition coefficients (LogK $\left.K_{O W}\right)$ of some organic compounds. $K_{F}$ and $n$ values were obtained by least square fitting.

\begin{tabular}{|l|c|c|c|c|}
\hline \multicolumn{1}{|c|}{ Compound } & LogKow & $\begin{array}{c}\mathrm{KF} \\
(\mathrm{L} \text { mmoln-1 kg-1) }\end{array}$ & $\mathrm{n}$ & $\mathrm{R} 2$ \\
\hline toluene & 1.5 & $4.0 \pm 0.1$ & $2.4 \pm 0.5$ & 0.968 \\
\hline cyclohexane & 3.8 & $40 \pm 5$ & $0.8 \pm 0.1$ & 0.966 \\
\hline o-xylene & 3.1 & $4.89 \pm 0.05$ & $3.7 \pm 0.2$ & 0.998 \\
\hline phenylmethanol & 1.1 & $16.1 \pm 0.7$ & $3.0 \pm 0.08$ & 0.953 \\
\hline phenol & 1.5 & $7.6 \pm 0.2$ & $1.13 \pm 0.09$ & 0.989 \\
\hline cyclohexanol & 1.6 & $1.2 \pm 0.3$ & $0.9 \pm 0.2$ & 0.938 \\
\hline
\end{tabular}

It is worth nothing that the $K_{F}$ values reported in literature for the sorption onto activated carbon, currently the most popular sorbent for organic compounds, and for other recently introduced sorbent materials $[14,15,16,17]$ are markedly higher than those reported in Table 1 for PCT. For example, $K_{F}$ values reported for the sorption of toluene and o-xylene onto activated carbon were respectively 35.8 and $54.8 \mathrm{~L}^{1 / n} \mathrm{mg}^{1-1 / n} \mathrm{~g}^{-1}[18]$; for phenol a $K_{F}$ value of $54.0 \mathrm{~L}^{1 / n} \mathrm{mg}^{1-1 / n} \mathrm{~g}^{-1}$ has been reported [19].

\section{CONCLUSIONS}

Despite its relatively low $\mathrm{Si} / \mathrm{Al}$ ratio, the zeolitic tuff analyzed in this study is a good sorbent of organic pollutants, particularly so for those with a low n-octanol/water partition coefficient. The sorption occurs, however, with a relatively low, but significant efficiency, as deduced from the Freundlich constants. In designing the use of zeolitic tuffs for water depuration by toxic cations, these results should be considered.

\section{REFERENCES}

[1] F.Pepe, B. de Gennaro, P.Aprea, D.Caputo (2013) Natural zeolites for heavy metals removal from aqueous solutions: Modeling of the fixed bed $\mathrm{Ba} 2+/ \mathrm{Na}+$ ion-exchange process using a mixed phillipsite/chabazite-rich tuff, Chemical Engineering Journal, 219, 37-42.

[2] S.Wang, Y.Peng (2010) Natural zeolites as effective adsorbents in water and wastewater treatment, Chemical Engineering Journal, 156, 11-24.

[3] B.Liguori, D.Caputo, F.lucolano, P.Aprea, B. de Gennaro (2013) Entrapping of Cs and Sr in heattreated zeolite matrices, Journal of Nuclear Materials, 435, 196-201.

[4] A.A.Halim, H.A.Aziz, M.A.M.Johari, K.S.Ariffin (2010) Comparison study of ammonia and COD adsorption on zeolite, activated carbon and composite materials in landfill leachate treatment, Desalination, 262, 31-35.

[5] P.Misaelides (2011) Application of natural zeolites in environmental remediation: A short review, Microporous and Mesoporous Materials, 144(1-3), 15-18.

[6] M.Khalid, G.Joly, A.Renaud, P.Magnoux (2004) Removal of Phenol from Water by Adsorption Using Zeolites, Industrial \& Engineering Chemistry Research, 43(17), 5275-5280.

[7] R.I.Yousef, B.El-Eswed, A.H.Al-Muhtase (2011) Adsorption characteristics of natural zeolites as solid adsorbents for phenol removal from aqueous solutions: Kinetics, mechanism, and thermodynamics studies, Chemical Engineering Journal, 171, 1143-1149.

[8] V.Rakic, N.Rajic, A.Dakovic, A.Auroux (2013) The adsorption of salicylic acid, acetylsalicylic acid and atenolol from aqueous solutions onto natural zeolites and clays: Clinoptilolite, bentonite and kaolin, Microporous and Mesoporous Materials, 166, 185-194.

[9] P.Vanore, E.Coppola, P.lovino, V.Leone, S.Salvestrini S.Capasso (2014) Sorption thermodynamics of organic pollutants onto zeolitic tuff: isosteric and standard enthalpy, Procedia Environmental Science, Engineering and Management, 1, 77-81.

[10] V.Leone, S.Canzano, P.lovino, S.Capasso (2012) Sorption of humic acids by a zeolite-feldsparbearing tuff in batch and fixed-bed column, Journal of Porous Matererials, 19, 449-453.

[11] P.T.Hang, G.W.Brindley (1970) Methylene blue absorption by clay minerals. Determination of surface areas and cation exchange capacities (clayorganic studies XVIII), Clays and Clay Minerals, 18, 203-212.

[12] T.Sainio, I.Turku (2010) Adsorption of cationic surfactants on a neutral polymer adsorbent: Investigation of the interactions by using mathematical modeling, Colloids and Surfaces A: Physicochemical and Engineering Aspects, 358(13), 57-67.

[13] S.Salvestrini, V.Leone, P.lovino, S.Canzano, S.Capasso (2014) Considerations about the correct 
evaluation of sorption thermodynamic parameters from equilibrium isotherms, J. Chem. Thermodynamics, 68, 310-316.

[14] V.Leone, S.Canzano, P.lovino, S.Salvestrini, S.Capasso (2013) A novel organo-zeolite adduct for environmental applications: Sorption of phenol, Chemosphere, 91, 415-420.

[15] V.Leone, P.lovino, S.Salvestrini, S.Capasso, (2014) Sorption of non-ionic organic pollutants onto a humic acids-zeolitic tuff adduct: Thermodynamic aspects, Chemosphere, 95, 75-80.

[16] P.lovino, V.Leone, S.Salvestrini, S.Capasso (2015) Sorption of non-ionic organic pollutants onto immobilized humic acid, Desalination and Water Treatment, 56(1), 55-62.
[17] V.Leone, P.lovino, S.Canzano, S.Salvestrini, S.Capasso (2013) Water Purification from humic acids by clinoptilolite-rich-tuff, Environmental Engineering and Management Journal, 12, 3-6.

[18] F.Su, C.Lu, S.Hu (2010) Adsorption of benzene, toluene, ethylbenzene and $\mathrm{p}$-xylene by $\mathrm{NaOCl}$ oxidized carbon nanotubes, Colloids and Surfaces A: Physicochemical. Engineering Aspects, 353, 8391.

[19] O.Hamdaoui, E.Naffrechoux (2007) Modeling of adsorption isotherms of phenol and chlorophenols onto granular activated carbon Part I. Twoparameter models and equations allowing determination of thermodynamic parameters, Journal of Hazardous Materials, 147, 381-394.

\section{IZVOD}

\section{SORPCIJA ORGANSKIH ZAGAĐIVAČA NA ZEOLITSKOM TUFU}

Izoterme, koje prikazuju sorpciju šest organskih zagađivača (fenil methanol - benzyl alcohol, fenol, cikloheksanol, o-ksilen, toluen i cikloheksan), iz vodenih rastvora, na zeolitskom tufu (Si/Al odnos =2.4), su određene šaržnim postupkom, na $25^{\circ} \mathrm{C}$, u rastvoru pufera $-1.0 \cdot 10^{-3} \mathrm{~mol}_{\mathrm{dm}}^{-3}$ Tris$\mathrm{HCl}(\mathrm{pH}$ 6.0). Rastvori su analizirani na gasnom hromatografu. Najbolje slaganje eksperimentalnih rezultata je postignuto sa Frojndlih-ovim sorpcionim modelom, čije konstante su određene $i$ upoređene sa literaturnim podacima.

Ključne reči: organski zagađivači, zeolitski tuff, sorpcija.

\section{Naučni rad}

Rad primljen: 25.03.2016.

Rad prihvaćen: 07.05.2016.

Rad je dostupan na sajtu: www.idk.org.rs/casopis 